\title{
Phytoplankton assemblages in two sub-basins of Lake Como
}

\author{
Fabio BUZZI \\ ARPA Lombardia, Dipartimento di Lecco, Via I Maggio, 21/b, I-23848 Oggiono (LC), Italy \\ e-mail: ARPALECCO@libero.it
}

\begin{abstract}
This paper reports the results of a two-year study on the chemical characteristics and phytoplankton assemblages in the western (Como) and eastern (Abbadia Lariana) sub-basins of Lake Como. The data were collected from September 1997 to August 1999 in the frame of an investigation financed by the Provincial Administration of Como and Lecco. Over the period of study TP concentrations ranged between 6-46 $\mu \mathrm{g} P l^{-1}$ at Abbadia, and 5-50 $\mu \mathrm{g} P l^{-1}$ at Como. Reactive phosphorus ranged between 6-31 $\mu \mathrm{g} P l^{-1}$ at

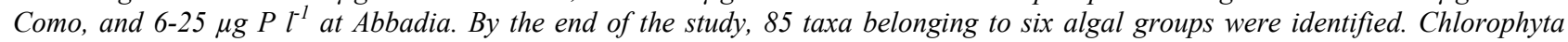
(Chlorophyceae and Conjugatophyceae) (30) were the best represented, followed by Bacillariophyceae (23), Cyanoprokaryota (8), Cryptophyceae (6), Chrysophyceae (6) and Dinophyceae (6). The time variation of chlorophyll a (0.5-9.72 $\left.\mu \mathrm{g} l^{-1}\right)$, phytoplankton density (177-64925 cell. $\left.\mathrm{ml}^{-1}\right)$ and biovolume $\left(21-6665 \mathrm{~mm} \mathrm{~m}^{3} \mathrm{~m}^{-3}\right.$ ) showed the same trend, with the lowest and maximum values recorded during winter and from spring to summer, respectively. In order to compare the seasonal succession in the two sub-basins, cluster analysis and non-metric multidimensional scaling ordination were used jointly. Multivariate analysis showed i) a substantial homogeneity in the time seasonality of the dominant phytoplankton assemblages in the two sub-basins and ii) a clear differentiation of summer phytoplankton from the other seasonal phases. From a purely quantitative point of view, there were dissimilarities between the two stations. The western sub-basin showed a greater algal production than Abbadia, especially in spring and summer. Despite the strong reduction of TP since the 1980s, the results of investigations carried out during the 1990s indicated a substantial stability of phytoplankton. It is emphasised that a reduction in biomass and shift in species composition will be possible only by assuring a severe control of the nutrient loads.
\end{abstract}

Key words: phytoplankton, Lake Como, deep lakes

\section{INTRODUCTION}

In origin the deep southern subalpine lakes were oligotrophic; successively, they underwent a progressive eutrophication as shown by the increase in nutrient concentrations and by palaeolimnological studies (Guilizzoni et al. 1982; Mosello \& Giussani 1997). In the early 1970s, the studies carried out on Lake Como demonstrated a strong dominance of few species, mainly belonging to cyanobacteria (Planktothrix rubescens and Gomphosphaeria lacustris) (Braga 1972). In the late 1970 s, total phosphorus concentrations at spring overturn reached their maximum $\left(80 \mu \mathrm{g} \mathrm{P}^{-1}\right)$ (Ambrosetti et al. 1983). In this period the phytoplankton assemblages were dominated by Stephanodiscus hantzschii in spring, and by Planktothrix rubescens and Gomphosphaeria lacustris in summer (Barbanti et al. 1986).

During the 1980s, the reduction of nutrient loads, following the abatement of phosphorus in detergents, caused a TP decrease in the Como basin, from $71 \mu \mathrm{g}$ P $\mathrm{l}^{-1}$ in 1986 (Mosello et al. 1991) to $40 \mu \mathrm{g} \mathrm{P}^{-1}$ measured at spring overturn, in 1992.

In 1994 the ARPA (Regional Environmental Protection Agency of Lombardy Region) Department of Lecco, with the cooperation of CNR Istituto Italiano di Idrobiologia (presently Istituto per lo Studio degli Ecosistemi) started an investigation on phytoplankton structure and dynamics in two stations located in the eastern basin: Abbadia Lariana and Lierna (Buzzi 1995). This paper reports the results obtained between September 1997 and August 1999 at the stations of Como (western basin) and Abbadia Lariana (eastern ba$\sin$ ). The research, financed by the Provinces of Como and Lecco, was carried out in the frame of a collaboration among University of Milan and the ARPA Departments of Lecco, Como and Sondrio. The data were elaborated by a common protocol in the frame of a research project devoted to the study of the trophic evolution of the deep southern subalpine lakes (Mosello \& Salmaso 2000).

\section{STUDY AREA}

Lake Como is the deepest Italian lake $(410 \mathrm{~m}$, in front of Argegno; Fig. 1); its surface and water volume are $146 \mathrm{~km}^{2}$ and $22.5 \mathrm{~km}^{3}$, respectively.

The catchment area covers $4522 \mathrm{~km}^{2}$, most of which is formed by calcareous rocks, especially dolomite, with marl and sandstone. Owing to its shape, resembling an upside-down "Y", Lake Como may be subdivided in three sub-basins, i.e. the Western, the Eastern and the Northern basins (Fig. 1). The bathymetric and the hydrological characteristics of the Western and Eastern basins, which are the objects of this paper, are very different. The western branch is separated from the rest of the lake by an underwater ridge and has a water renewal time of 8.3 years. The eastern branch, with a regular 
bottom and the presence of the outlet at its southern edge, has a lower renewal time. The water renewal time of the whole lake has been estimated in 12.8 years (Buzzi et al. 1997).

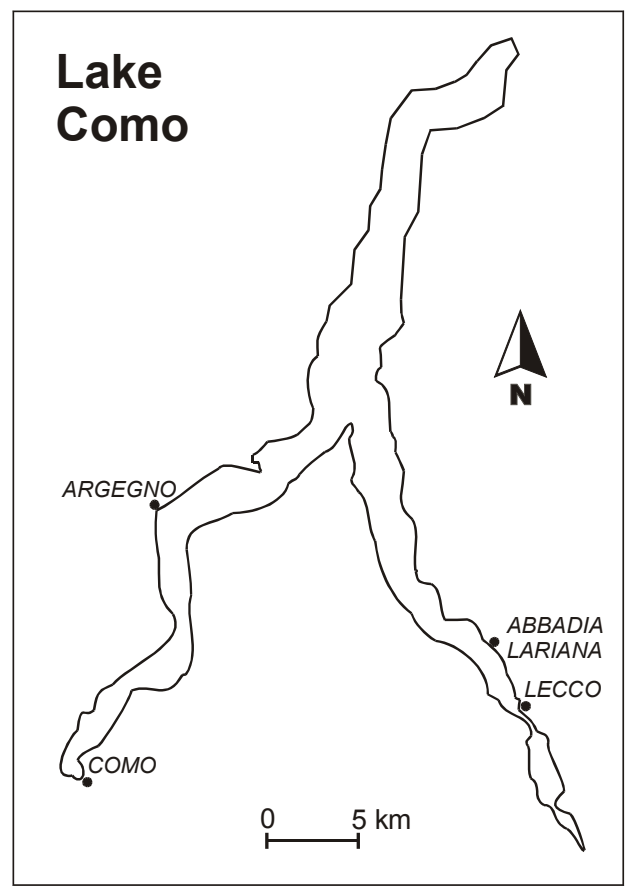

Fig. 1. Map of Lake Como and location of the sampling stations.

Lake Como is oligomictic, with the spring mixing typically involving the first $150-200 \mathrm{~m}$, a complete turnover being rare ( Ambrosetti \& Barbanti 1992). In 1999 a complete mixing of the water column was observed at the deepest point (Argegno).

The climate of this area is intermediate between middle-European and northern-Mediterranean; annual precipitations are mainly concentrated in spring and autumn.

\section{METHODS}

Monthly samplings were carried out in the stations of Como $\left(Z_{\max }=100 \mathrm{~m}\right)$ and Abbadia Lariana $\left(Z_{\max }=\right.$ $135 \mathrm{~m})$ from September 1997 to August 1999; each sampling date at Como was shifted of 1 or 2 weeks in respect of the corresponding sampling at Abbadia. Integrated samples for phytoplankton analyses were obtained from the layer $0-20 \mathrm{~m}$ by mixing sub-samples collected every two meters with a Ruttner bottle. In the two stations, two subsamples were fixed with acetic Lugol's solution and formaldehyde, respectively. In order to identify small centric diatoms, aliquots of subsamples fixed in formaldehyde were oxidised with hydrogen peroxide and then mounted on glass slides. The subsamples fixed in Lugol's solution were analysed with an inverted microscope (Leica IMDL), following the Utermöhl technique (Utermöhl 1958). The smallest algae (including ultraplankton, up to $4 \mu \mathrm{m}$ ) were identified at $400 \times$, whereas the less abundant and larger organisms were determined at $200 \times$, until 400 individuals for the most abundant species were reached. Phytoplankton biovolume was estimated from density data and measurements of specific cell volume obtained approximating cell shapes to simple geometrical solids (Rott 1981).

Species were identified following the series Süsswasserflora von Mitteleuropa (established by A. Pascher) and Das Phytoplankton des Süsswassers (established by G. Huber-Pestalozzi). The taxonomy of Oscillatoriales was based on the updating by Anagnostidis \& Komárek (1988).

Chlorophyll- $a$ was determined by spectrophotometry (Lorenzen 1967) after filtration of the 0-20 m integrated samples on Whatman GF-F glass-fiber filters, disruption of the filters with a grinder and $24 \mathrm{~h}$ extraction in $90 \%$ acetone.

In the two stations, samples for chemical analyses were collected at $0,2.5,5,10,20,30,50,80$ and $100 \mathrm{~m}$; further samples at $135 \mathrm{~m}$ were collected at Abbadia Lariana. Soluble reactive and total phosphorus (SRP, $\mathrm{TP})$, nitrate and ammonium nitrogen $\left(\mathrm{NO}_{3}-\mathrm{N}, \mathrm{NH}_{4}-\mathrm{N}\right)$ were measured following standard methods (A.P.H.A, A.W.W.A and W.E.F., 1995). The analytical procedures are described in Mosello et al. (1999). Dissolved oxygen and temperature profiles were obtained in situ using a multiparametric WTW probe. Values of the chemical variables in the upper $20 \mathrm{~m}$ were estimated averaging the single values obtained from samples collected at discrete depths.

Water transparency was measured with a Secchi disk without the aid of a bathyscope. The euphotic depth $\left(Z_{\mathrm{eu}}\right)$ (Talling 1971) was estimated from Secchi disk transparency $\left(Z_{\mathrm{s}}\right)$ as suggested in Tilzer (1988), using the relationship:

$$
\mathrm{Z}_{\mathrm{eu}}=5.02 \times \mathrm{Z}_{\mathrm{s}}^{0.70}
$$

Major phytoplankton seasonal modifications in the two stations were evaluated from the changes inside the assemblages of the dominant species, namely those species which, at least once during the whole seasonal cycle, contributed to build up $80 \%$ of the total community biovolume. Moreover, in order to evaluate the annual phytoplankton cycle in the two sub-basins during 1998, cluster analysis (average linkage) and non-metric multidimensional scaling ordination (NMDS) were used jointly (Salmaso 1996). Both techniques were applied to a dissimilarity matrix obtained from the calculation of Bray-Curtis index (Bray \& Curtis 1957) after transformation of the original data by double square root.

\section{RESULTS}

\subsection{Physical parameters}

In the upper 20-30 m, a pronounced stratification was observed in the two stations from July to October 

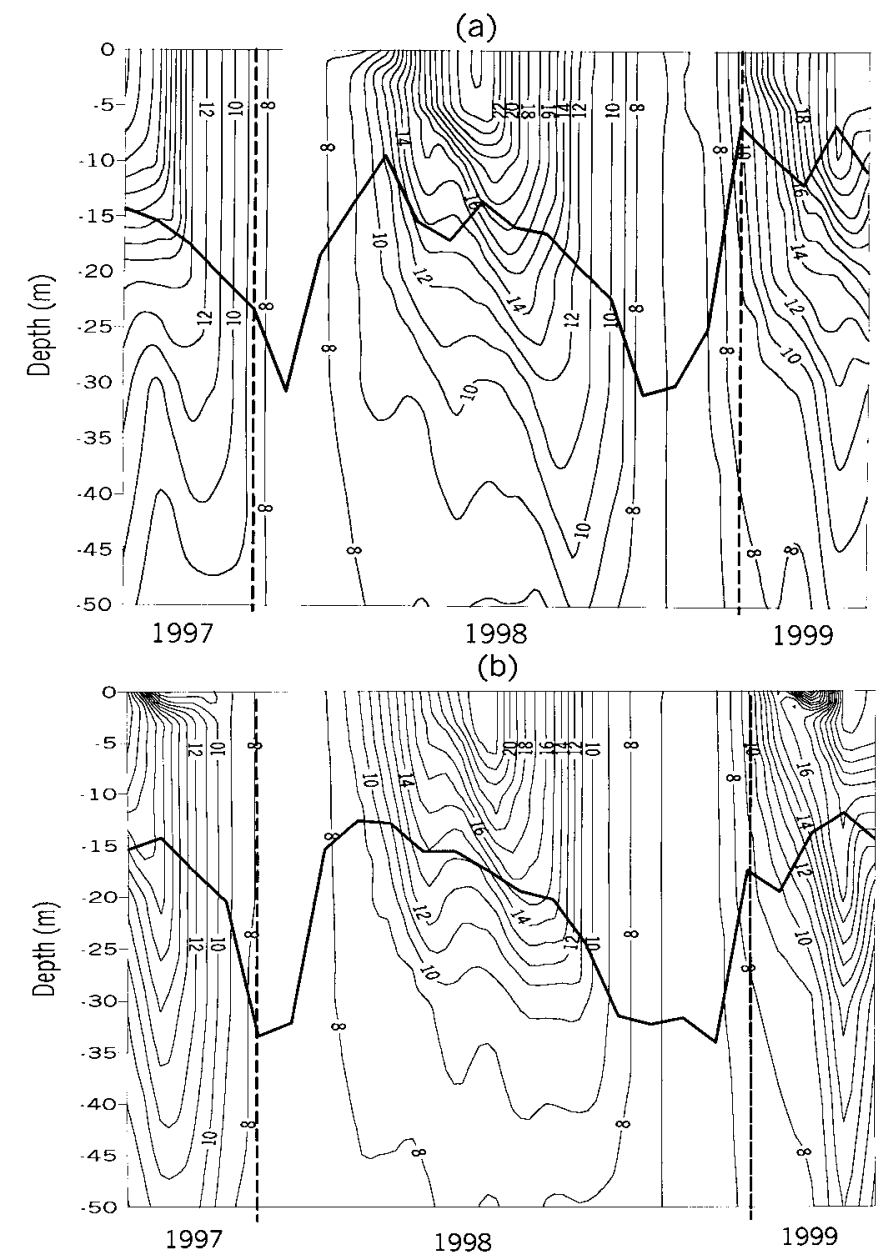

Fig. 2. Isopleths of temperature $\left({ }^{\circ} \mathrm{C}\right)$ with superimposed seasonal variation of the euphotic depth $(\mathrm{m})$ at Como (a) and Abbadia Lariana (b).

(Fig. 2). In the sampled layers (0-100 $\mathrm{m}$ at Como and 0$135 \mathrm{~m}$ at Abbadia) a complete homogenisation took place from January to March. Maximum water temperatures in the stations of Como and Abbadia were observed in August $\left(24.6\right.$ and $23.5^{\circ} \mathrm{C}$, respectively).

The lowest values of transparency $(1.5 \mathrm{~m})$ were recorded in April and July 1999 in the western basin (Fig. $3 \mathrm{~d})$; the highest value $(15 \mathrm{~m})$ was recorded in January 1998 in the eastern basin. The limit of the euphotic zone was between $15-30 \mathrm{~m}$ during the autumn and winter months, and between $6.6-15.0 \mathrm{~m}$ in spring and summer. The thickness of the mixed layer $\left(Z_{\mathrm{m}}\right)$ exceeded $Z_{\text {eu }}$ during the colder months, whereas $Z_{\text {eu }}$ exceed $Z_{m}$ in summer, from June to September.

\subsection{Chemical characteristics}

The time course of oxygen (percent saturation) and $\mathrm{pH}$ were parallel, even along the depth gradient in the epilimnion, with maximum values in summer and minimum in the coldest month (Figs $4 \mathrm{a}, \mathrm{b}$ ). In October 1997 the lowest $\mathrm{pH}$ (7.3) and dissolved oxygen saturation $(13 \%)$ values were recorded in the metalimnetic zone at Como $(30 \mathrm{~m})$. The highest $\mathrm{pH}$ in the western basin was recorded, at $5 \mathrm{~m}$ depth, in August 1998 (9.3); in the eastern basin the maximum values (9.0) were recorded at the surface, in July and August 1999.

Temporal variations of conductivity at Abbadia Lariana (Fig. 4c) were similar to the changes in alkalinity values, suggesting an impact of the precipitation of calcium carbonate caused by algal $\mathrm{CO}_{2}$ depletion during summer. In the western basin conductivity was probably influenced, from May to July 1998, by conspicuous loads of industrial waste, common in this basin; this could be indicated by the high $\mathrm{NH}_{4}-\mathrm{N}$ concentration recorded in July $1998\left(160 \mu \mathrm{g} \mathrm{N}^{-1}\right)$ and in the high annual mean computed in $1998\left(52.2 \mu \mathrm{g} \mathrm{N} \mathrm{l}^{-1}\right)$.

In the layer $0-20 \mathrm{~m}$, annual average values of total phosphorus concentrations in 1998 were 27.4 and 15.6 $\mu \mathrm{g} \mathrm{P}^{-1}$ in the western and eastern basins, respectively; the minimum and maximum values during the entire period of study were 17.2-42.6 and 4.1-36.6 $\mu \mathrm{g} \mathrm{P} \mathrm{l}^{-1}$ at Como and Abbadia Lariana, respectively (Fig. 4d). Reactive phosphorus ranged between 2.5-30.2 $\mu \mathrm{g} \mathrm{P} \mathrm{l}^{-1}$ at Como, and 2.5-27.4 $\mu \mathrm{g} \mathrm{P} \mathrm{l}^{-1}$ at Abbadia Lariana. 
(a)

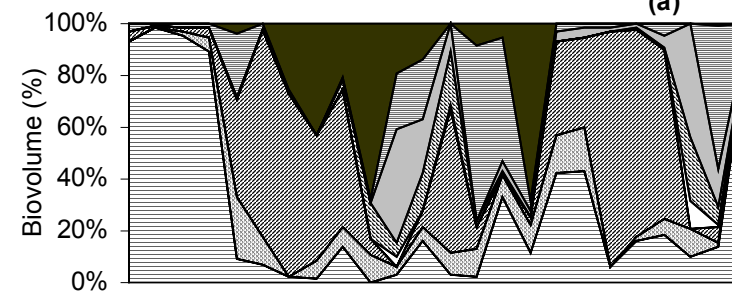

$\square$ Cyanob. $\square$ Cryptoph. $\square$ Bacillarioph. $\square$ Chrysoph.

$\square$ Chloroph. $\square$ Conjugatoph. 目Dinoph.

$\square$ Ultrap./Flag.

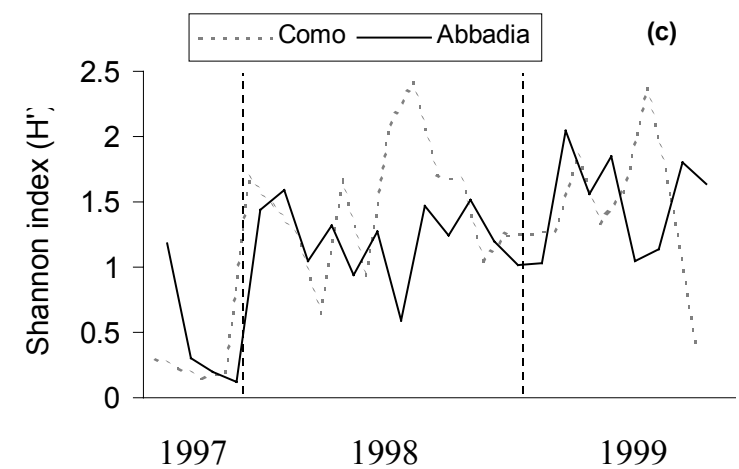

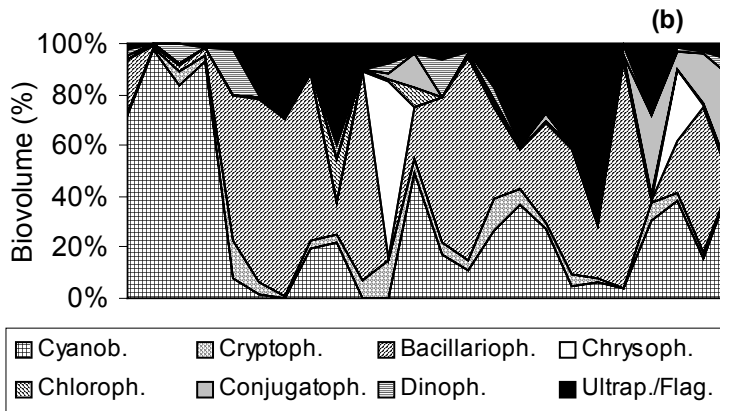

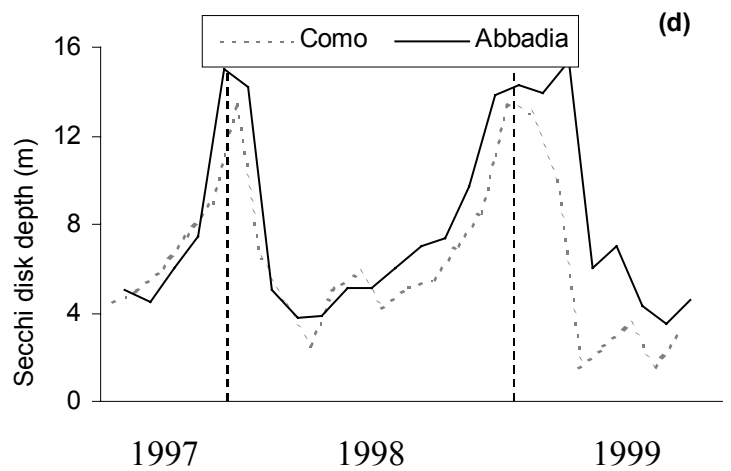

Fig. 3. Changes in the percentage contribution of phytoplankton groups to total biovolume at Como (a) and Abbadia (b). The temporal variations of the diversity index and transparency are reported in (c) and (d).
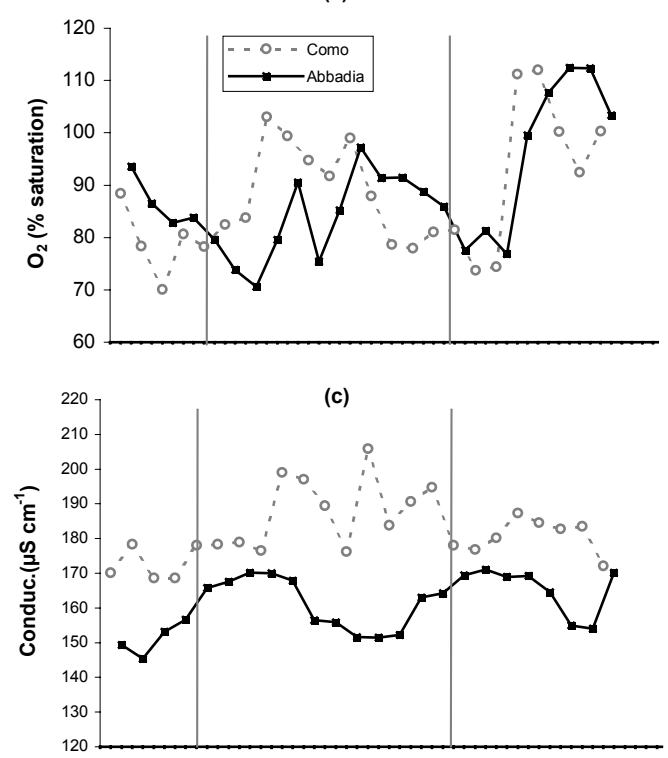

(e)

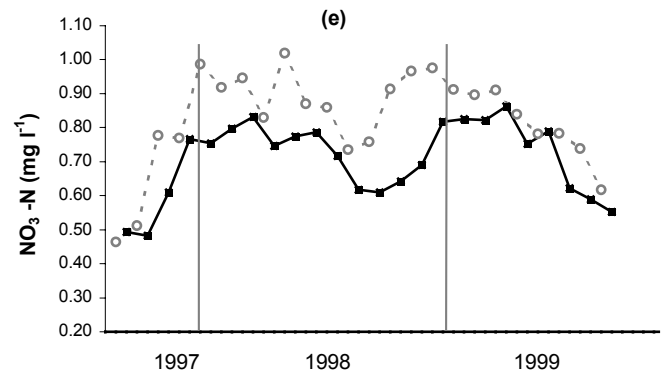

(b)

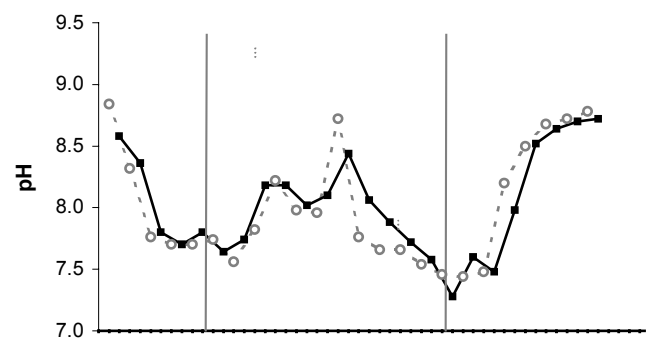

(d)

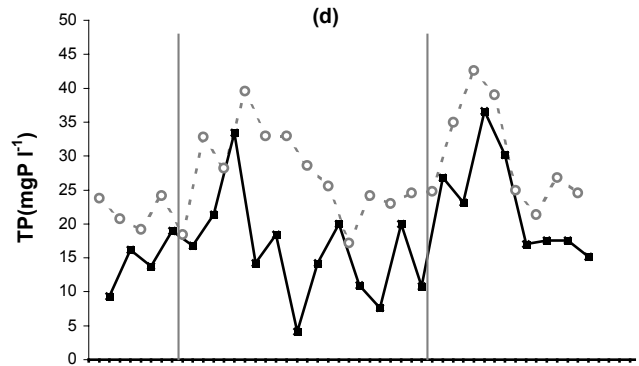

(f)

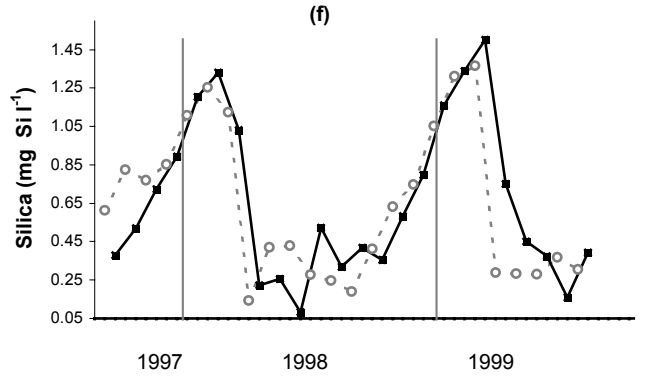

Fig. 4. Temporal variation of dissolved oxygen (a), $\mathrm{pH}(\mathbf{b})$, conductivity $(\mathbf{c})$, total phosphorus (d), nitrate nitrogen (e) and reactive silica (f) in the layer $0-20 \mathrm{~m}$. 

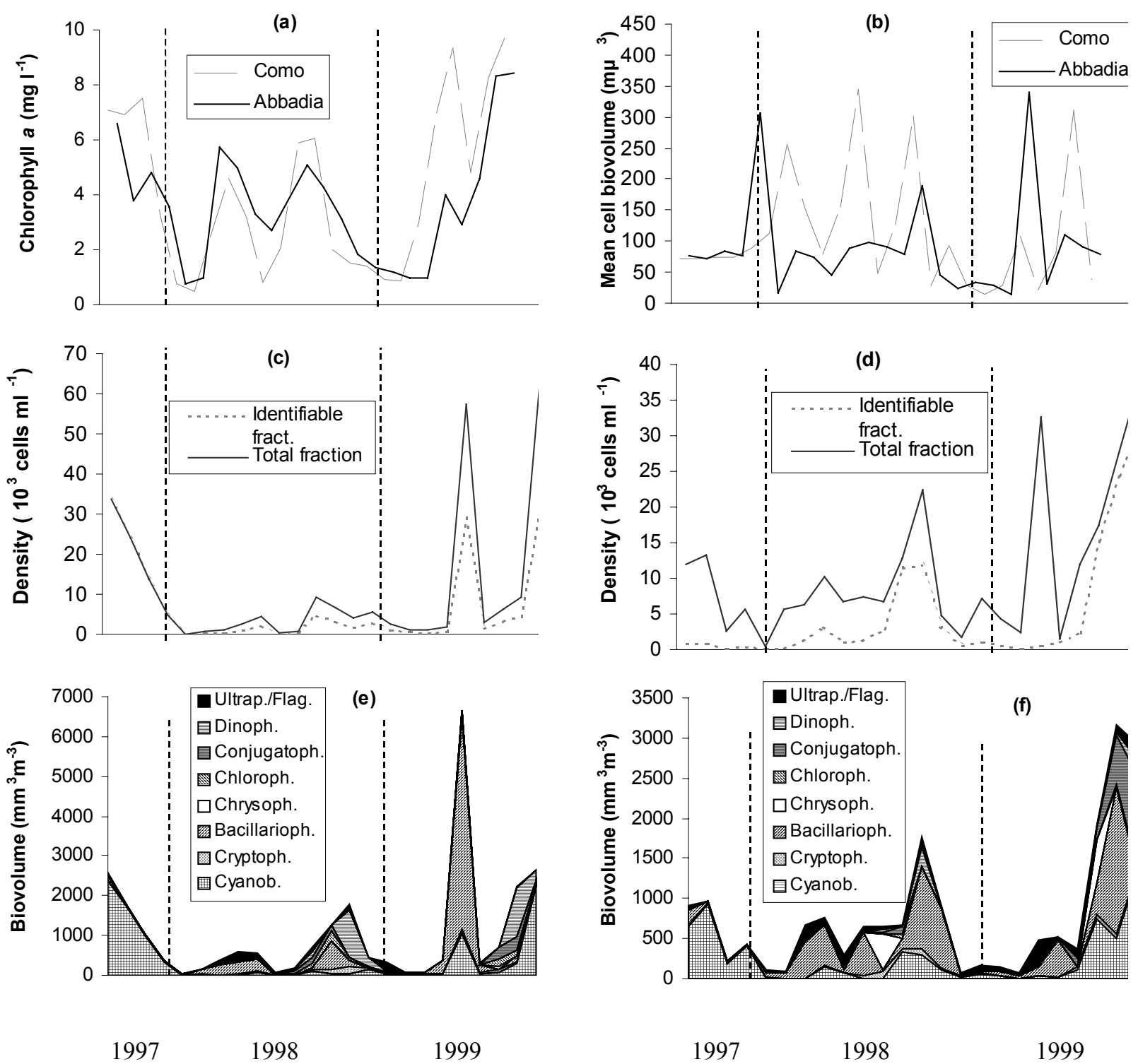

Fig. 5. Temporal variations of clorophyll- $a$ (a) and mean cellular biovolume (b) in the two sampling stations. Phytoplankton density and biovolume at Como (c, e) and Abbadia (d, f).

Minimum concentrations of $\mathrm{NO}_{3}-\mathrm{N}$ were recorded in September 1997, in the western basin (Fig. 4e), during the maximum development of cyanobacteria. All in all, $\mathrm{NO}_{3}-\mathrm{N}$ concentrations in the layers $0-20 \mathrm{~m}$ ranged between $c a 0.46-1.0 \mathrm{mg} \mathrm{N} \mathrm{I}^{-1}$; however, at the surface, minimum $\mathrm{NO}_{3}-\mathrm{N}$ concentrations reached a value of 0.25 $\mathrm{mg} \mathrm{N} \mathrm{l}^{-1}$ (Como, 2 September 1997). Annual mean values in 1998 were 0.90 and $0.74 \mathrm{mg} \mathrm{N}^{-1}$ in the western and eastern basins, respectively.

Silica concentrations in the layer $0-20 \mathrm{~m}$ were lowest from late spring to mid summer. Minimum and maximum values were recorded at Abbadia Lariana in June 1998 (0.084 $\left.\mathrm{mg} \mathrm{l}^{-1}\right)$ and March 1999 (1.5 mg Si $\left.1^{-1}\right)$. At the surface, minimum Si concentrations were recorded in June 1998, at Abbadia Lariana (0.01 mg Si $\left.1^{-1}\right)$.

\subsection{Density, biovolume and chlorophyll-a}

Figure 5a shows the temporal variations of chlorophyll- $a$ in the two sampling stations. The lower concentrations at Abbadia Lariana were recorded in winter (with a minimum of $0.8 \mu \mathrm{g} \mathrm{l}^{-1}$ in January 1998); the maximum concentration was recorded during August $1999\left(8.4 \mu \mathrm{g} \mathrm{l}^{-1}\right)$; the annual mean in 1998 was $3.2 \mu \mathrm{g}$ $1^{-1}$. The western basin exhibited seasonal variations of chlorophyll- $a$ similar to the eastern one, but with the minimum and maximum values occurring in February $1998\left(0.5 \mu \mathrm{g} \mathrm{l}^{-1}\right)$ and August $1999\left(9.7 \mu \mathrm{g}^{-1}\right)$; the annual mean in 1998 was $2.6 \mu \mathrm{g} \mathrm{l}^{-1}$.

Phytoplankton biovolume and density values are reported in figures $5 \mathrm{e}-\mathrm{f}, \mathrm{c}-\mathrm{d}$. In general, the seasonal evo- 
Tab. 1. List of the dominant taxa, common to both stations, that have contributed at least in one occasion to the $80 \%$ biovolume of all the determined taxa, peaks of biovolume of each species and species frequency in both stations over the total phytoplankton biovolume.

\begin{tabular}{|c|c|c|c|c|c|c|}
\hline & \multicolumn{2}{|c|}{ Dominant taxa } & \multicolumn{2}{|c|}{ Biovolume $\mathrm{mm}^{3} \mathrm{~m}^{3}$} & \multicolumn{2}{|c|}{ Frequency $\%$} \\
\hline & Abbadia & Como & Abbadia & Como & Abbadia & Como \\
\hline \multicolumn{7}{|l|}{ CYANOBACTERIA } \\
\hline Planktothrix rubescens & + & + & 961 & 2177 & 79 & 96 \\
\hline Gomphosphaeria lacustris & + & + & 162 & 22 & 25 & 29 \\
\hline Limnothrix sp. & + & + & 55 & 244 & 75 & 83 \\
\hline \multicolumn{7}{|l|}{ CHLOROPHYCEAE } \\
\hline Eudorina elegans & & + & & 59 & & 4 \\
\hline Pediastrum boryanum & & + & & 71 & & 4 \\
\hline Sphaerocystis schroeteri & & + & & 10 & & 8 \\
\hline Nephrocitium agardhianum & & + & & 49 & & 8 \\
\hline \multicolumn{7}{|l|}{ CONJUGATOPHYCEAE } \\
\hline Mougeotia sp. & + & + & 1006 & 257 & 46 & 33 \\
\hline Staurastrum gracile & + & & & 224 & & 29 \\
\hline \multicolumn{7}{|l|}{ CHRYSOPHYCEAE } \\
\hline Dinobryon sociale & + & + & 443 & 4 & 8 & 4 \\
\hline Uroglena americana & + & & 540 & & 4 & \\
\hline \multicolumn{7}{|l|}{ BACILLARIOPHYCEAE } \\
\hline Asterionella formosa & + & + & 183 & 4720 & 75 & 33 \\
\hline Fragilaria crotonensis & + & + & 1784 & 559 & 92 & 83 \\
\hline Tabellaria fenestrata & + & + & 534 & 75 & 29 & 17 \\
\hline Stephanodiscus parvus & + & + & 289 & 138 & 38 & 25 \\
\hline Aulacoseira islandica & + & + & 136 & 250 & 42 & 29 \\
\hline Aulacoseira cfr. ambigua & + & & 78 & & 21 & \\
\hline Cyclotella comensis & + & & 75 & & 13 & \\
\hline Synedra acus & + & + & 52 & 22 & 29 & 8 \\
\hline Melosira varians & + & + & 43 & 50 & 21 & 17 \\
\hline \multicolumn{7}{|l|}{ CRYPTOPHYCEAE } \\
\hline Rhodomonas minuta & + & + & 61 & 85 & 71 & 100 \\
\hline Cryptomonas erosa & + & & 18 & & 38 & \\
\hline Cryptomonas ovata & & + & & 13 & & 21 \\
\hline \multicolumn{7}{|l|}{ DINOPHYCEAE } \\
\hline Ceratium hirundinella & + & + & 1179 & 1231 & 42 & 46 \\
\hline Peridinium sp. & & + & & 53 & & 4 \\
\hline Gymnodinium sp. & + & & 1 & & 13 & \\
\hline
\end{tabular}

lution of phytoplankton abundance shows a trend comparable to that of chlorophyll- $a$. In particular, chlorophyll- $a$ and biovolume showed a significant correlation during the whole study period $(\mathrm{r}=0.55, \mathrm{P}<0.05$ at Como and $\mathrm{r}=0.79, \mathrm{P}<0.05$ at Abbadia).

The highest biovolume at Como was recorded in April $\left(6665 \mathrm{~mm}^{-3} \mathrm{~m}^{-3}\right)$, during a high development of Asterionella formosa; annual mean values in 1998 and during the entire study period were 531 and $1053 \mathrm{~mm}^{-3}$ $\mathrm{m}^{-3}$, respectively. The maximum density value, recorded in August 1999 (64925 cell ml ${ }^{-1}$ ), was also due to a strong contribution of ultraplankton (Fig. 5d). In the eastern basin (Fig. 5f) maximum biovolume and density values $\left(2994 \mathrm{~mm}^{-3} \mathrm{~m}^{-3}\right.$ and 37560 cell $\mathrm{ml}^{-1}$ ) were recorded in August 1999, during a high development of Fragilaria crotonensis; annual mean values in 1998 and during the entire study period were 559 and $792 \mathrm{~mm}^{-3}$ $\mathrm{m}^{-3}$, respectively.

In 1998, and during the whole study period, the mean cellular biovolumes, obtained from the ratio between total biovolume values and total density values (Fig. 5b), were 62-111 $\mu^{3}$ at Como, and 95-91 $\mu \mathrm{m}^{3}$ at
Abbadia Lariana, respectively. The differences among the mean biovolume in the two stations are mainly due to different contributions of the ultraplanktonic cells.

The mean chlorophyll- $a$ content per unit biovolume ranged between 1-37 and 2-23 $\mathrm{pg} \mathrm{mm}^{-3}$ in the western and eastern basins, respectively.

\subsection{Composition and species dynamics}

By the end of the study period, 85 taxa belonging to six groups were identified. Chlorophyta (Chlorophyceae and Conjugatophyceae) (30) were the best represented, followed by Bacillariophyceae (23), Cyanoprokaryota (8), Cryptophyceae (6), Chrysophyceae (6) and Dinophyceae (6).

The dominant taxa, identified in the two stations, are listed in table 1. This table of this table reports the species that, starting from the most abundant, have contributed at least in one occasion to the $80 \%$ biovolume of all the determined taxa; for every species, biovolume peaks are indicated together with the occurrence (in percent) of each species in the whole study period and in the two stations. 
At least two species, Fragilaria crotonensis and Planktothrix rubescens, have continuously characterised, with high biovolume values, the phytoplankton assemblage. Other species, like Tabellaria fenestrata and Mougeotia sp. in the western basin, and Asterionella formosa in the eastern basin, were less frequent, showing a single, conspicuous peak during their annual development.

The seasonal evolution of some selected dominant taxa (cf. Tab. 1) is reported in figure 6. During the complete thermal homogenisation of the water column (January and February), the dominant taxa in the western basin were Fragilaria crotonensis and Rhodomonas minuta in 1998, Planktothrix rubescens, Fragilaria crotonensis and Aulacoseira islandica in 1999. In the eastern basin the situation was different only in 1999, when Melosira varians and Aulacoseira cf. ambigua gave an important contribution to the phytoplankton assemblage.

During early spring, $A$. formosa and $F$. crotonensis were the most abundant species; in the station of Como, in April 1999, A. formosa reached the highest biovolume value recorded in this study $\left(4720 \mathrm{~mm}^{-3} \mathrm{~m}^{-3}\right)$. Other taxa, such as $A$. islandica and $A$. cf. ambigua gave a minor contribution to the assemblage. At Abbadia Lariana Stephanodiscus parvus was the dominant species in March and April 1998.

In late spring and early summer, with the start of thermal stratification, a transition occurred from a community dominated by diatoms to more diversified assemblages; Chlorophyceae (Sphaerocystis schroeteri and Pediastrum boryanum) and Conjugatophyceae (Staurastrum gracile and Mougeotia sp.) were the most abundant taxa in the western basin. In May and June 1998, in the eastern basin, P. rubescens, T. fenestrata and Carteria globosa were the most important species; in 1999 there was a bloom of Uroglena americana, with densities up to 300,000 cell ml$^{-1}$ along the littoral zone.

In the early and middle summer period, with stable water column stratification, phytoplankton assemblages at Como showed a different development in 1998 and 1999. In 1998 many species (such as S. gracile, Mougeotia sp., Ceratium hirundinella, Nephrocitium agardhianum and many others) contributed to $80 \%$ biovolume, especially in August, when the diversity index reached its maximum value (Fig. $3 \mathrm{c}$ ).

Small Cyanobacteria belonging to Chroococcales (e.g. Gomphosphaeria lacustris and Aphanocapsa sp.) were abundant in this period. In 1999 P. rubescens, (82\% of total biovolume in August), C. hirundinella and Mougeotia sp. dominated the algal community. In 1999, the same dominant species found at Como were noticed also at Abbadia Lariana, with the addition of $P$. rubescens, G. lacustris and Dinobryon sociale.

During late summer the assemblages were characterised by a high development of $P$. rubescens in 1997
(2314 $\mathrm{mm}^{-3} \mathrm{~m}^{-3}$ in September), and F. crotonensis and C. hirundinella in 1998.

As mixing depth increased, the autumn and early winter assemblages were mainly constituted by three species, i.e. P. rubescens, Rhodomonas minuta and Limnothrix sp.

\subsection{Seasonal evolution of the algal assemblage in 1998}

The dendrogram obtained by cluster analysis indicates a similar pattern of phytoplankton succession in the two stations (Fig. 7). The highest hierarchical level denotes a separation of the summer samples from all the others. The single seasons can be identified at a lower level of dissimilarity. Winter (W) and spring (SP) samples were grouped in single clusters, while summer (S1 to S4) and autumn (A1 and A2) were subdivided into sub-groups.

By the NMDS technique I could reveal a chronological ordination of the different groups identified by cluster analysis (Fig. 8; the "stress" of the configuration equals to 0.17 ). In particular, along the first axis of the two dimensional configuration, the summer samples are distinguished from the others; by contrast, the differences among the winter, spring and autumn groups are less evident.

The most important feature of the samples belonging to the winter group (W) was the low biovolume. This group is characterised by a weak dominance of $F$. crotonensis, A. islandica, $R$. minuta and Melosira varians.

The spring group was strongly dominated by diatoms. At Abbadia, the centric diatom Stephanodiscus parvus was the main taxon, followed by $A$. islandica; at Como, large colonial diatoms, mainly $A$. formosa, followed by Fragilaria crotonensis, dominated the assemblages.

After the stabilisation of the water column, large diatoms progressively decreased in favour of other taxa. In this period the distance between the groups in the NMDS configuration increased, indicating a strong intensification of the assemblage turnover (Fig. 8). Both cluster analysis and NMDS indicate that in summer the differences between the assemblages of the two stations were at their maximum.

The first summer phase includes the samples of June (S1, Como; S2, Abbadia). S1 was characterised by $S$. schroeteri and $R$. minuta, while in S2 T. fenestrata was the main taxon. Similarly, the algal assemblages of the two mid-summer groups (S3, S4; July-August) were rather different in the two stations, even though, in general, both were characterised by a similar development of chlorophytes. The station of Abbadia, in July, was dominated by $D$. sociale, while $S$. gracile and $C$. hirundinella gave an important contribution to the assemblage at Como. In August, P. rubescens and Mougeotia sp. gave the main contribution to the biovolume in the stations of Abbadia and Como, respectively. 


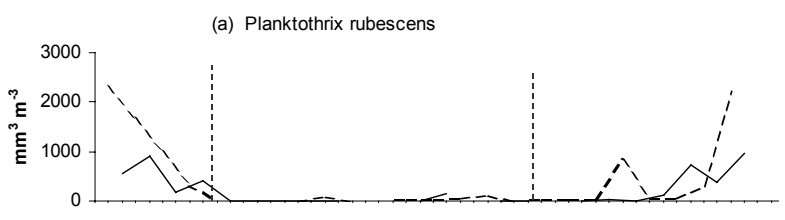

(b) Gomphosphaeria lacustris

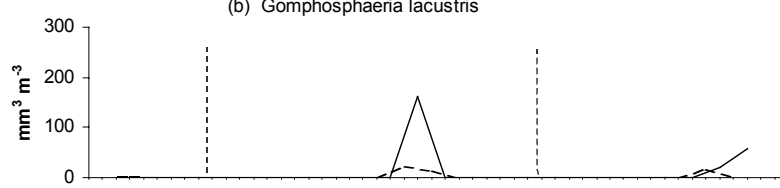

(c) Limnothrix sp.
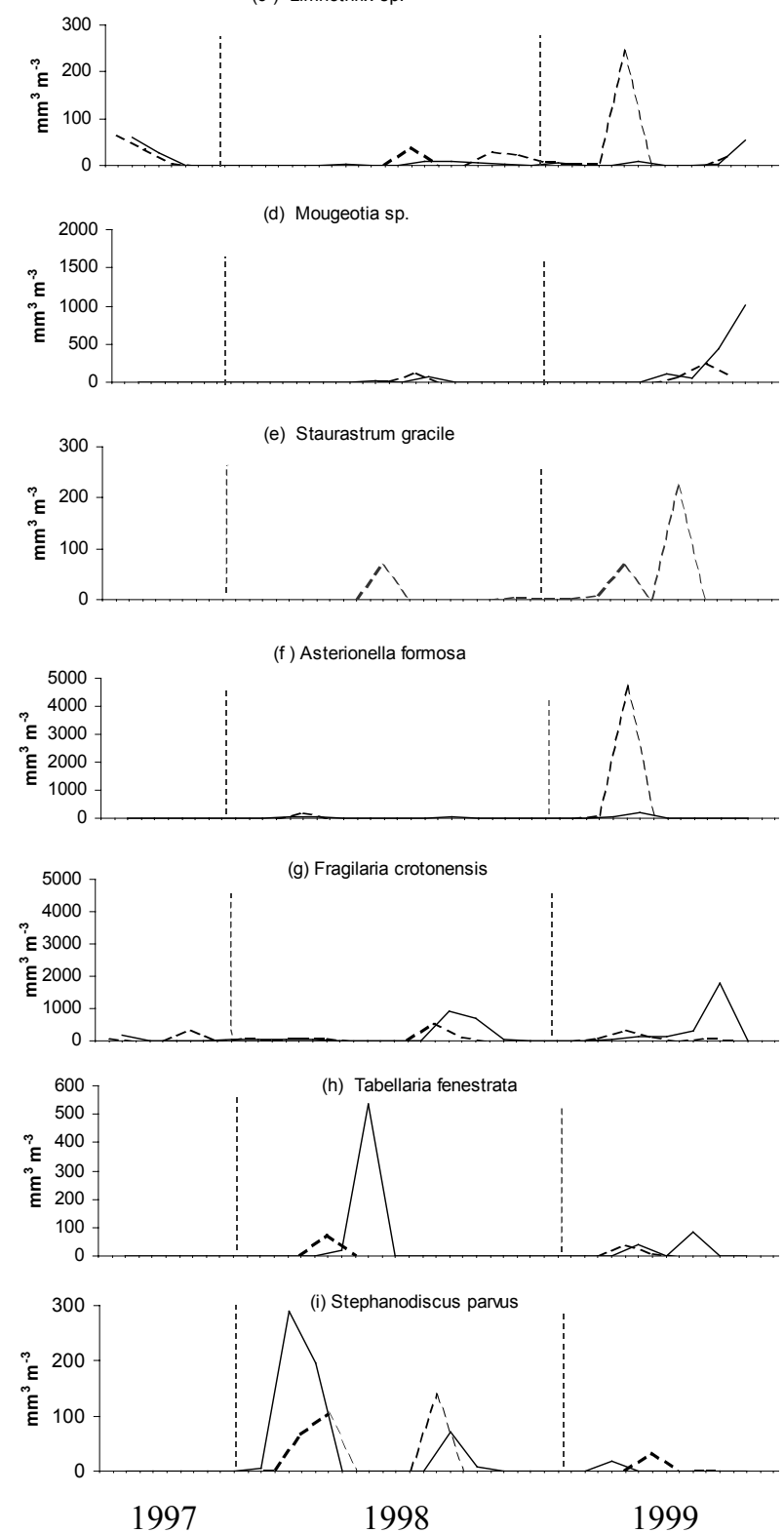
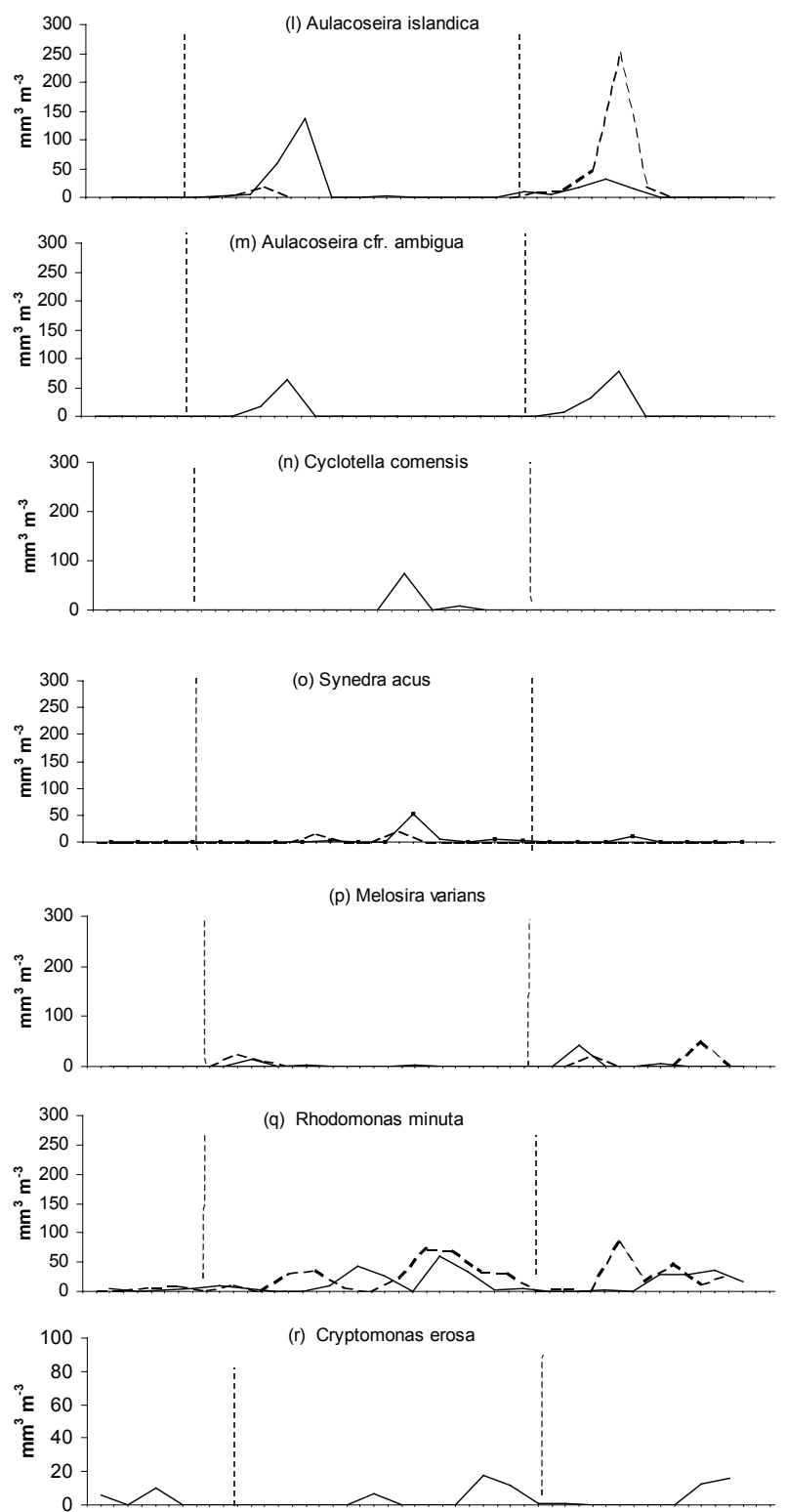

(s) Cryptomonas ovata
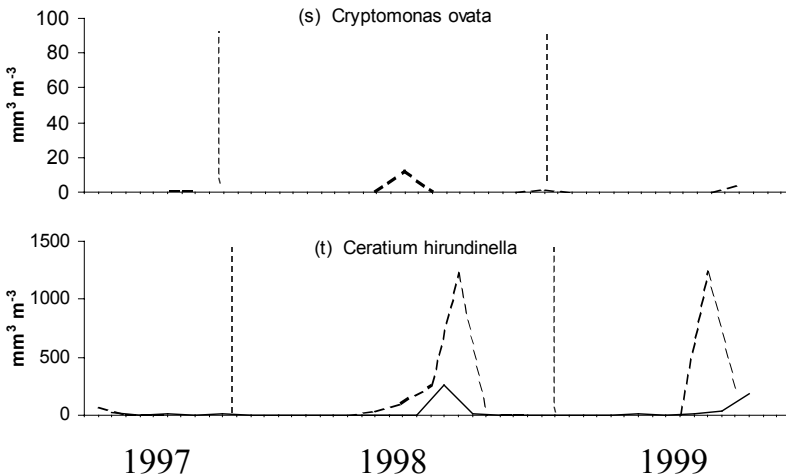

Fig. 6. Temporal variations of biovolume for selected dominant species of the groups Cyanobacteria (a-c), Coniugatophyceae (d-e), Bacillariophyceae (g-p), Cryptophyceae (q-s) and Dinophyceae (t). Broken line: Como St.; solid line: Abbadia St. 


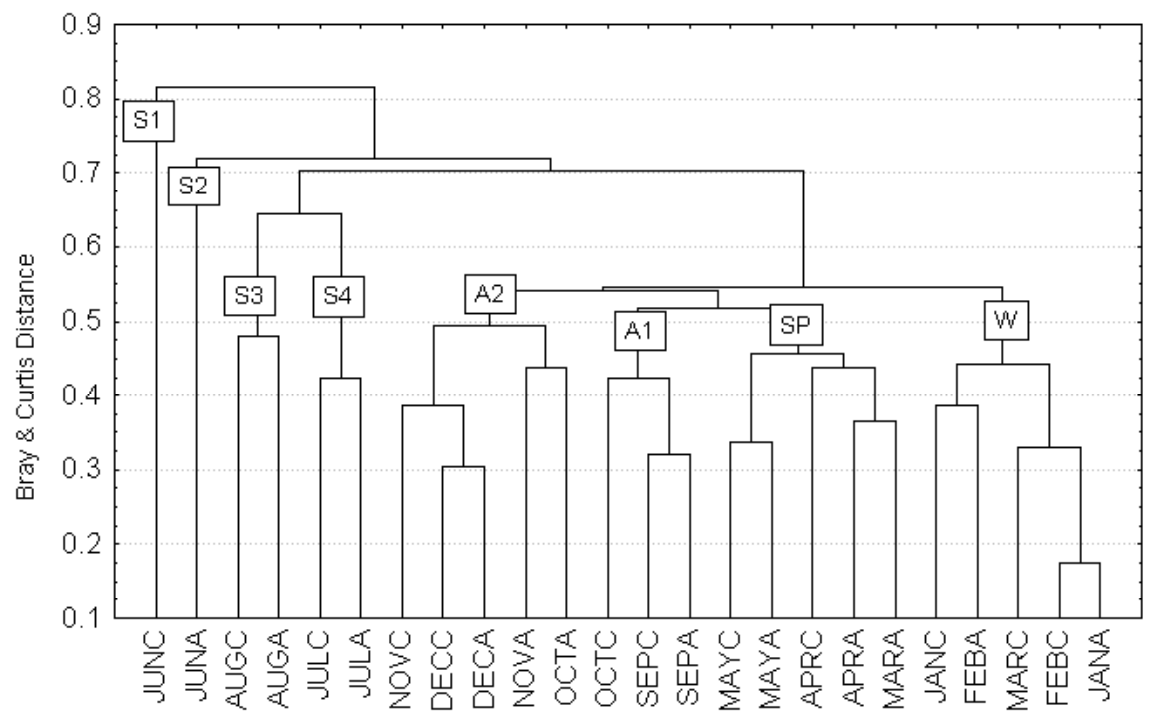

Fig. 7. Dendrogram showing the results of the classification of samples from Lake Como. The samples are named according to the month and the station $(\mathrm{C}=\mathrm{Como}, \mathrm{A}=\mathrm{Abbadia}$ Lariana $)$.

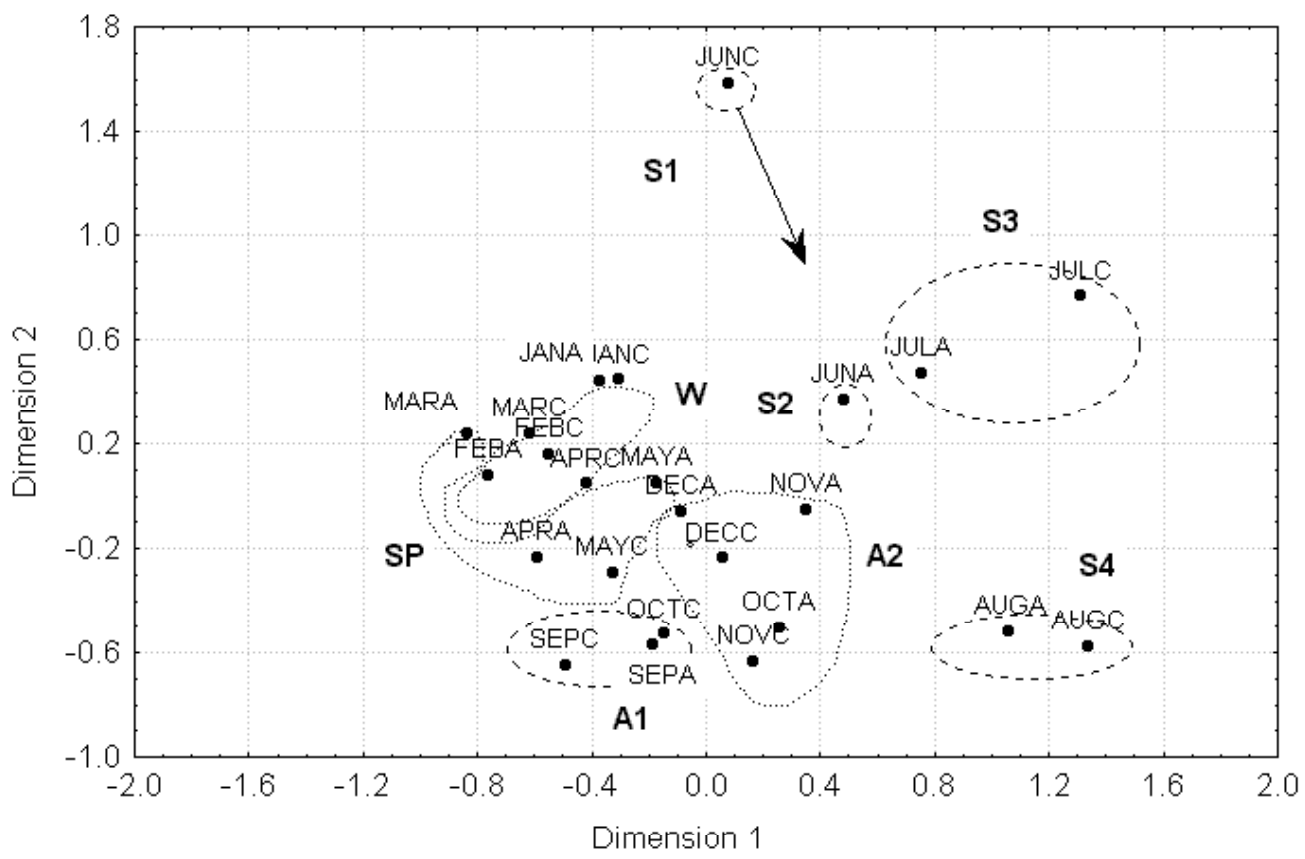

Fig. 8. Ordination of samples in the two-dimensional NMDS configurations. Groups are numbered as in figure 7. The arrow shows the direction of the succession.

The early autumnal phase (A1) was dominated, with high biovolume, by $F$. crotonensis, $P$. rubescens and $C$. hirundinella. The late autumn group (A2) stood out for a progressive decrease of biovolume and the appearance of Limnothrix sp. and A. islandica.

\section{DISCUSSION}

The seasonal development of phytoplankton is strictly associated with the temporal variations of some important environmental factors. It is known that during winter, with the lowest values of $Z_{e u} / Z_{m}$ ratio, low algal growth is due, to low irradiance and water temperature, as well as to the dilution of algal cells along the water column. The increasing of illumination with the progress of winter, the high availability of nutrients and high water column turbulence are a group of factors which strongly support the development of large colonial ( $\mathrm{As}$ terionella and Fragilaria) and medium-large centric diatoms (Stephanodiscus and Aulacoseira). Many diatoms have in general low threshold under minimum 
light (cf. Sommer 1987) favouring growth in well mixed waters; moreover, large diatoms can maintain large over wintering vegetative populations which may rapidly grow and became dominant after the winter months (cf. Reynolds 1984). The decrease of turbulence, resulting from water column stabilisation, and the exhaustion of silica are important factors for the decline of large diatoms (Sommer 1987); however, owing to the dependence of diatom populations from the net rate of increase (nutrient dependent) and losses (sinking and mortality), it is difficult to ascertain the relative impact of these two factors. Many studies show that cultured diatoms can growth until Si is reduced to $c a 5 \mu \mathrm{g} \mathrm{Si}^{-1}$ (Reynolds 1984). In this investigation (cf. Fig. 4f), minimum concentrations of silica in the layer 0-20 m (0.084-0.144 mg $\mathrm{Si}^{-1}$ ) are still suitable for diatom growth, but probably not enough to maintain a positive net balance in a progressively stabilised water column (cf. Salmaso 2000). Tabellaria fenestrata was the last diatom to develop with large biovolumes before summer; this was probably favoured also by the photosynthetic properties of this species, which is adapted to light intensities apparently inhibitory for the low light adapted species like Fragilaria and Asterionella (Reynolds 1984).

The summer period is characterised by intensifying thermal stratification which reduces the uptake of nutrients from the hypolimnion and determines a rapid segregation of resources along the water column, with major niche differentiation in early and mid summer. During these months, sinking, grazing losses and nutrient depletion assume a more critical role in controlling community composition. Some morphological and behavioural adaptations like small size, motility (flagellated organisms) density reduction (mucilaginous colonies) and buoyancy control (e.g. cyanobacteria) should be seen primarily as mechanisms prolonging the residence times of algal populations in the upper illuminated layers. Many of the taxa that develop during the summer months (e.g. many Chlorococcales, G. lacustris, $C$. hirundinella, D. sociale and $P$. rubescens) share a few of these adaptations. In particular, P. rubescens is homogeneously vertically distributed during circulation and exhibits a metalimnetic accumulation during the summer months. This is due to its ability to regulate its vertical position, and favoured by its adaptation to conditions of low irradiance (Lampert \& Sommer 1997). These properties allow a strong dominance of this species in late summer and autumn, when the progressive mixing of the water column determines a strong rearrangement of the community, with the disappearance of Chroococcales and the sporadic reappearance of Fragilaria.

From late summer to spring, multivariate analysis revealed a substantial homogeneity in phytoplankton evolution between the two sub-basins. Only during early summer the assemblages were less homogeneous. The different evolution of phytoplankton in the west and east basins during thermal stratification, and after the decline of large diatoms, reflects a different rate of change in the communities. However, this situation was likely amplified by the different sampling calendar in the two stations.

The peaks and the average values of biovolume, transparency and chlorophyll- $a$ at Como indicate a greater algal production than at the station of Abbadia, especially in spring and summer. According to the PEG model (Sommer et al. 1986), the development of abundant summer phytoplankton should be a function of nutrient availability during the spring months. TP concentrations at spring overturn in 1998 and 1999 were similar in the two sub-basins; on the contrary, during the rest of the year, TP concentrations were often lower at Abbadia. Considering the different physiographic properties of the two sub-basins, the differences of algal production between the two stations may be the consequence not only of nutrient availability, but also of hydrological events. This aspect, coupled with a clear classification and quantification of industrial loads discharged in the western basin (cf. section 4.2), should be faced by future environmental and limnological investigations in Lake Como.

The lower algal biovolumes (Figs 5e, f), and the apparently smaller utilization of $\mathrm{N}^{-\mathrm{NO}_{3}}$ (Fig. 4e) during the spring and summer months in 1998, testify a smaller algal development than in 1997 and 1999. In this connection a lower development of Planktothrix rubescens in the western basin should be noted. However, the lower algal biomasses observed in 1998 do not seem linked to a different availability of TP (cf. Fig. 3d). Physical factors should also be considered in an indepth analysis (e.g. hydrology, meteorological events).

Referred to the whole study period, biovolume composition in the western basin was dominated by cyanobacteria $(50 \%)$, followed by diatoms $(26 \%)$ and Cryptophyceae $(12 \%)$. In the eastern basin, diatoms were the most abundant (35\%), followed by cyanobacteria (31\%), ultraplankton (8\%) and Chrysophyceae (5\%). The mean biovolume values were lower in 1998 (531 and $559 \mathrm{~mm}^{-3} \mathrm{~m}^{-3}$ at Como and Abbadia, respectively) than during the entire period (1053 and $\left.792 \mathrm{~mm}^{3} \mathrm{~m}^{-3}\right)$. All in all, these values fall within the interval 500-2000 $\mathrm{mm}^{3} \mathrm{~m}^{-3}$ defined by Rott (1984) as characteristic of mesotrophic lakes.

The most recent study on the phytoplankton of Lake Como was carried out from February to October 1997 in three stations located in the western basin (Bettinetti et al. 2000) . Compared to the present work, the results revealed a common dominance of $P$. rubescens in late summer, autumn and early winter, and of $R$. minuta in late autumn and winter. Spring was characterized by the same diatom assemblage as in the present work, with some differences in relative abundances: in spring 1997 the most abundant diatom was Stephanodiscus hantzschii, whereas in the spring of 1998 and 1999 the 
dominant diatoms were $A$. formosa and $F$. crotonensis. Other species, such as $A$. islandica, gave a lower contribution to phytoplankton biovolumes.

In the present investigation, two biovolume maxima (in spring and late summer) were found. Bettinetti et al. (2000) recorded only one maximum value in autumn; moreover, the phytoplankton biovolume and density values recorded by these authors were generally higher than those found in the present study; this was also observed in September and October 1997, the two months sampled in the course of both investigations. These differences may depend, at least in part, on to the different sampled layers, i.e. 0-10 metres (Bettinetti et al. 2000) and 0-20 metres (present study).

In the eastern basin the most recent studies were made by Chiaudani \& Premazzi (1993) and Buzzi (1995). A comparison with these two papers is not reliable; in the first case a different approach was used to determine phytoplankton abundance; in the second case, samples were collected with a lower sampling frequency. However, species like $F$. crotonensis, $P$. rubescens and $R$. minuta were the most important in the assemblages described in the two mentioned papers, just as in the present one.

\section{CONCLUSIONS}

Since the 1980s a decrease of TP concentrations in the water column of Lake Como was recognised (from ca $75 \mu \mathrm{g} \mathrm{P} \mathrm{l}^{-1}$ down to $40-50 \mu \mathrm{g} \mathrm{P}^{-1}$ in the first half of the 1990s; Mosello et al. 1997, 1999, 2001). The lower algal nutrient availability caused a significant decrease of some dominant species such as Microcystis aeruginosa and Melosira granulata, which are usually associated with eutrophic environments. In the second half of the 1990s, the decrease of TP came to an end, and phytoplankton communities did not undergo major changes, as confirmed by a study on sedimentary diatoms (Marchetto \& Bettinetti 1995).

The present nutrient concentrations in the two subbasins are around $35 \mu \mathrm{g} \mathrm{TP} 1^{-1}$ (Mosello et al. 1999, 2001). However, a considerable amount of phosphorus is sequestered in the deep hypolimnion, thus deferring complete or higher replenishment of nutrients in the euphotic layers until years of complete or more extended episodes of vertical mixing. With favourable environmental conditions (e.g. enhanced water column stability), the high trophic potential of Lake Como may be suitable for the development of cyanobacterial blooms. In August 2000, a bloom of M. aeruginosa developed in the entire western branch, with a maximum density of 300,000 cell ml ${ }^{-1}$ (ARPA-Lombardia; unpublished Technical Report).

Despite the strong reduction of TP since the 1980s, the results of investigations carried out during the 1990s indicated a substantial stability of the phytoplankton assemblage. This is in accord with the statement by Sas (1989) on the recovery pattern observed in deep lakes after the reduction of phosphorus. At present, Lake Como is in the phase where the dominant species are adapting to reduced resource levels. In the future, a reduction in biomass and shift in species composition should be observed, provided that a severe control of the nutrient loads discharged into the lake will be adopted.

Future studies on the algal communities should become an indisputable feature in the management of Lake Como, because of phytoplankton populations rearrange their biomass and composition in reply to changing nutrient levels and trophic conditions. However, the knowledge of meteorological and hydrological data is a necessary step to identify the most relevant factors influencing the seasonal alternation of the dominant phytoplankton species.

\section{ACKNOWLEDGMENTS}

My thanks are due to Giuseppe Morabito and Nico Salmaso for the great help they gave me in writing this paper; to Luigi Naselli Flores for his comments and suggestions and to Delio Ruggiu who revised the manuscript. Thanks are also due to Provincia of Lecco and Provincia of Como that haved financed this study.

\section{REFERENCES}

A.P.H.A, A.W.W.A. \& W.E.F. 1995. Standard methods for the examination of water and wastewater. 19th ed. American Public Health Association, Washington.

Ambrosetti, W. \& L. Barbanti. 1992. Physical Limnology: an historical review. Mem. Ist. ital. Idrobiol., 50: 37-60.

Ambrosetti, W., L. Barbanti, R. Mosello, A. Rolla \& D. Ruggiu. 1983. Mescolamento, caratteristiche chimiche, fitoplancton e situazione trofica nei laghi profondi subalpini. CNR Collana del Progetto Finalizzato Promozione della qualità dell'Ambiente, $\mathrm{AQ} / 2 / 20: 151 \mathrm{pp}$.

Anagnostidis, K. \& J. Komàrek. 1988. Modern approach to the classification system of cyanophytes. 3-Oscillatoriales. Arch. Hydrobiol., Suppl. 80: 327-472.

Barbanti, L., R. Mosello, A. Pugnetti \& D. Ruggiu. 1986. La limnologia del Lario: dai primi studi alle ricerche attuali. Proc. Symp. Risanamento del Lago di Como: la ricerca scientifica. Como 25 ottobre: 217-237.

Bettinetti, R., G. Morabito \& A. Provini. 2000. Phytoplankton assemblage structure and dynamics as indicator of the recent trophic and biological evolution of the western basin of Lake Como (N. Italy). Hydrobiologia, 435: 177-190.

Braga, L. 1972. Quadro limnologico recente (1970-1971) del Lago di Como: aspetti fisici e chimici, popolamento fitoplanctonico e produzione primaria. Tesi di Laurea, Università degli Studi di Milano: $97 \mathrm{pp}$.

Bray, J. R. \& J. T. Curtis. 1957. An ordination of the upland forest communities of Southern Wisconsin. Ecol. Monogr., 27: 325-349.

Buzzi, F. 1995. Osservazioni sui popolamenti fitoplanctonici del ramo orientale del Lago di Como nel quadro della sua evoluzione trofica. Atti II Convegno Nazionale di Fisica dell'Ambiente, Cosenza 1995.

Buzzi, F., G. Gerosa \& G. Salvadè. 1997. Descrizione e analisi di alcuni aspetti limnologici e idrodinamici del Lago di Como. Documenta Ist. ital. Idrobiol., 61: 93-115.

Chiaudani G. \& G. Premazzi. 1993. Il Lago di Como. Condizioni ambientali e modello di previsione dell'evoluzione della qualità delle acque. Rapporto CCR EUR 15267 IT: $237 \mathrm{pp}$. 
Guilizzoni, P., G. Bonomi, G. Galanti \& D. Ruggiu. 1982. Basic trophic status and recent development of some Italian lakes as revealed by plant pigments and other chemical components in sediment cores. Mem. Ist. ital. Idrobiol., 40: 79-88.

Kenkel, N.C. \& L. Orlóci. 1986. Applying metric and nonmetric multidimensional scaling to ecological studies: some new results. Ecology, 67: 919-928.

Lampert, W. \& U. Sommer. 1997. Limnoecology: the ecology of Lakes and Streams. Oxford-University-Press-Incorporated, New York: 382 pp.

Lorenzen, C.J. 1967. Determination of chlorophyll and phaeopigments: spectrophotometric equations. Limnol. Oceanogr., 12: 343-346.

Marchetto, A. \& R. Bettinetti. 1995.Reconstruction of the phosphorus history of two deep, subalpine Italian lakes from sedimentary diatoms, compared with long-term chemical measurements. Mem. Ist. ital. Idrobiol., 53:27-38

Mosello, R. \& G. Giussani (Eds). 1997. Evoluzione recente della qualità delle acque dei laghi profondi sudalpini. Documenta Ist. ital. Idrobiol., 61: 228 pp.

Mosello, R. \& N. Salmaso. 2000. Cooperazione per lo studio della qualità delle acque dei laghi profondi sudalpini (QuAlps): obiettivi e primi risultati. Atti della Giornata di Studio: I Laghi come Risorsa per lo Sviluppo. Milano, 16 ottobre 1998. Politecnico di Milano, Consiglio Regionale della Lombardia, CNR-III Pallanza e Associazione ex Consiglieri Regionali della Lombardia: 39-50.

Mosello, R., A. Calderoni \& R. de Bernardi. 1997. Le indagini sulla evoluzione dei laghi profondi sudalpini svolte dal CNR Istituto Italiano di Idrobiologia. Documenta Ist. ital. Idrobiol., 61: 19-32.

Mosello, R., D. Ruggiu, A. Pugnetti \& M. Moretti. 1991. Observed trends in the trophic conditions and possible recovery of the deep subalpine Lake Como (Northern Italy). Mem. Ist. ital. Idrobiol., 49: 79-98.

Mosello, R., M.C. Brizzio, L. Garibaldi, F. Buzzi, L. Colzani, E. Pizzotti \& D. Mocellin. 1999. Attuali condizioni trofiche dei bacini di Como e Lecco del Lario. Acqua \& Aria, 9: 71-81.
Mosello, R., M.C. Brizzio, F. Buzzi, L. Colzani, E. Pizzotti \& D. Mocellin. 2001. Qualità delle acque dei tributari e del Lario nel biennio 1998-1999. Atti Associazione Italiana Oceanologia e Limnologia, 14: 137-146.

Reynolds, C.S. 1984. The ecology of freshwater Phytoplankton. Cambridge University press, Cambridge: 384 pp.

Rott, E. 1981. Some results from phytoplankton counting intercalibrations. Schweiz Z. Hydrol., 43: 34-62

Rott, E. 1984. Phytoplankton as biological parameter for the trophic characterisation of lakes. Vehr. int. Ver. Limnol., 22: 1078-1085.

Salmaso, N. 1996. Seasonal variation in the composition and rate of change of the phytoplankton community in a deep subalpine lake (Lake Garda, Northern Italy). An application of nonmetric multidimensional scaling and cluster analysis. Hydrobiologia, 337: 49-68.

Salmaso, N. 2000. Factors affecting the seasonality and distribution of cyanobacteria and chlorophytes: a case study from the large lakes south of the Alps, with special reference to Lake Garda. Hydrobiologia, 438: 43-63.

Salmaso, N. \& F. Decet. 1997. Seasonal and interannual changes of chemical characteristics and phytoplankton in a mountain lake of the eastern Italian Alps (Lake Calaita, Trentino). Int. Rev. ges. Hydrobiol., 82: 15-31.

Sas, H. (Ed.). 1989. Lake restoration by reduction of nutrient loading: expectations, experiences, extrapolations. Accademia Verlag Richarz, St. Augustin: 497 pp.

Sommer, U. 1987. Factors controlling the seasonal variation in phytoplankton species composition. A case study for a deep, nutrient rich lake. Prog. Phyc. Res., 5: 123-178.

Sommer, U., Z. M. Gliwicz, W. Lampert \& A. Duncan. 1986. The PEG model of seasonal succession of planktonic events in fresh waters. Arch. Hydrobiol., 106: 433-471.

Talling, J.F. 1971. The underwater light climate as a controlling factor in the production ecology of freshwater phytoplankton. Mitt. int. Ver. Limnol., 19: 375383.

Tilzer. 1988. Secchi disk - chlorophyll relationships in a lake with high variable phytoplankton biomass. Hydrobiologia, 162: 163-171.

Utermöhl, H. 1958. Zur Vervollkommung der quantitative Phytoplankton- Metodik. Mitt. int. Ver.Limnol., 9: 1-38. 